Pak. j. sci. ind. res. Ser. B: biol. sci. 201356 (1) 36-40

\title{
Determination of Limonin and Nomilin Contents in Different Citrus Cultivars Using High Performance Liquid Chromatography
}

\author{
Hazrat Bilal $^{a *}$, Waseem Akram ${ }^{\mathrm{b}}$, Soaib Ali Hassana ${ }^{\mathrm{a}}$, Sumrin Sahar ${ }^{\mathrm{a}}$ and \\ Muhammad Munir Iqbal ${ }^{\mathrm{c}}$ \\ ${ }^{a}$ Health Services Academy, Opposite NIH, Chak Shahzad, Islamabad, Pakistan \\ ${ }^{b}$ Department of Agri-Entomology, University of Agriculture Faisalabad, Pakistan \\ 'National Institute for Genomic and Advance Biotechnology, NARC, Islamabad, Pakistan \\ (received April 5, 2012; revised October 31, 2012; accepted November 18, 2012)
}

\begin{abstract}
High performance liquid chromatography (HPLC) analysis was done to quantify the amount of limonoids (limonin and nomilin) in seven selected citrus cultivars. According to the HPLC analysis red blood orange (Citrus sinensis var red blood orange) had maximum amount of limonin $(479.77 \mu \mathrm{g} / \mathrm{mL})$, while rough lemon (Citrus jambhiri) had no limonin content. In case of nomilin, rough lemon (Citrus jambhiri) had maximum amount of nomilin $(54.23 \mu \mathrm{g} / \mathrm{mL})$, while succari (Citrus sinensis var succari) had very low amount of nomilin $(0.37 \mu \mathrm{g} / \mathrm{mL})$.
\end{abstract}

Keywords: limonin, nomilin, HPLC, citrus fruits

\section{Introduction}

Plants are considered to have secondary metabolites, which are helpful in defense, healing mechanism and having anticarcinogenic effects. Citrus (Rutaceae) are well known for having such compounds. Secondary metabolites are usually complex and unique carbon structures (Sarker et al., 2005), having different chemical groups like alkaloids, terpenoids, phenolic, plant amines, rare amino acids and glycosides (Rohloff, 2003). Monoterpenes (Langenheim, 1994), terpenoids (Gutierrez et al., 1997) are used in protecting the plants from herbivore or competitor. Plants use terpenoids in plant-plant interactions which serve as attractants for pollinators (Tholl, 2006). Cyanogenic glycosides, isoflavonoids and alkaloids which are soluble secondary compounds can also be toxic to animals (Morris and Robbins, 1997). These also play an important role in nutrition of food and animal feed with a number of phenolic compounds. Limonoids are a group of chemicals related to terpenoids found in Rutaceae and Meliaceae families of the Order Rutales. Out of 38 limonoids reported to occur in citrus and its hybrids (Jayaprakasha et al., 1997), citrus fruits posses a wide variety of bioactive compounds with health promoting disease preventing properties, effective against cancer. Moreover, limonoids from Rutaceae particularly 'Citrus' (Klocke and Kubo, 1982) have attracted greater concern due to their growth regulating

\footnotetext{
*Author for correspondence; E-mail: bilalento@yahoo.com
}

activity (Champage et al., 1992) besides having anticarcinogenic effects (Sohail et al., 2005) and their ability to treat tumor cell lines (Poulose et al., 2005; Tada et al., 1999), suggesting their importance as natural chemo preventatives or as therapeutics or nutraceuticals obtained from 'Citrus' by-products (Schoch et al., 2002; Widmer and Montanari, 1996). The present study was undertaken for screening of new sources of limonoids among Citrus spp. as natural source of metabolites.

\section{Materials and Methods}

Collection of citrus cultivars. Different citrus cultivars i.e., Chakutra (Citrus grandis), Kinnow (Citrus reticulate), Musambi (Citrus sinensis var. musambi), Narangi (Citrus mitis), red blood orange (Citrus sinensis var. red bloob orange), rough lemon (Citrus jambhiri) and succari (Citrus sinensis var. succari) were collected from citrus growing areas of Sargodha (Punjab) and Khanpur (Khyber Pakhtoonkhwa) Pakistan.

HPLC analysis. Instrument. HPLC apparatus was comprised of a Shimadzu (Japan), Shimadzu degasser unit (DGU-12A) and pump (LC-10AT) with a Shimadzu ultraviolet (UV) detector (SDD-10AV). Limonoids were quantified on $\mathrm{C} 18$ reverse phase Shim Pack CLC-ODS column, $5 \mu \mathrm{m}$ particle size $(15 \mathrm{~cm} \times 4.6 \mathrm{~mm})$ and detected at $210 \mathrm{~nm}$. 
Preparation of mobile phase and standards. HPLC grade methanol, acetonitrile (Merck Germany), standards (nomilin and limonin) from MP Biochemical's (France) and water were used in the preparation of mobile phase with the 10:41:49 ratio. Stock solution was prepared by adding $5 \mathrm{mg}$ of limonin and nomilin in $100 \mathrm{~mL}$ of mobile phase.

Chromatographic conditions. The elution was monitored by UV absorption at $210 \mathrm{~nm}$ with $1 \mathrm{~mL} / \mathrm{min}$ flow rate. Millipore filter $(0.45 \mu \mathrm{m})$ was used for the filtration of both standards and samples. The linearity of method was estimated by analyzing standards. $20 \mu \mathrm{L}$ of each standard was injected in HPLC and elution was carried out isocratically and peak responses with their respective retention time were obtained. Filtered samples $(20 \mu \mathrm{L})$ were injected in $\mathrm{C} 18$ reverse phase column, eluted isocratically with acetonitrile, methanol, and water (10:41:49).

Statistical analysis. The compounds were quantified by chromatography station software CSW 32, version 1.4.11.89. The limonoid aglycones were identified on the basis of retention times and quantified (Ohta et al., 1993). Peaks were recorded with standards at retention time of $8.15 \mathrm{~min}$ (limonin) and $12.66 \mathrm{~min}$ (nomilin).

\section{Results and Discussion}

Citrus fruits contain certain compounds (limonoids) that are extremely bitter which are mainly accumulated in seeds (Faisal et al., 2011) and by-products (Dandekar et al., 2008; Schoch et al., 2001; Hasegawa, 2000). Non-volatile collection through HPLC analysis was done and the responsive peaks at specific retention time were recorded (Fig. 1). The highest content of limonin was found in red blood orange $(479.77 \mu \mathrm{g} / \mathrm{mL})$, followed by succari (426.77 $\mu \mathrm{g} / \mathrm{mL})$, kinnow (99.62 $\mu \mathrm{g} / \mathrm{mL})$, musambi (42.63 $\mu \mathrm{g} / \mathrm{mL})$, chakutra $(39.87 \mu \mathrm{g} / \mathrm{mL})$ while narangi and rough lemon had almost $0.77 \mu \mathrm{g} / \mathrm{mL}$ and $0 \mu \mathrm{g} / \mathrm{mL}$ limonin content, respectively as shown in Table 1.

According to Table 1, rough lemon $(54.23 \mu \mathrm{g} / \mathrm{mL})$ has the highest nomilin contents, followed by musambi (41.67 $\mu \mathrm{g} / \mathrm{mL})$, narangi $(11.85 \mu \mathrm{g} / \mathrm{mL})$, chakutra (6 $\mu \mathrm{g} / \mathrm{mL})$, kinnow $(3.91 \mu \mathrm{g} / \mathrm{mL})$ while red blood orange and succari have the lowest level of nomilin contents, i.e., $1.49 \mu \mathrm{g} / \mathrm{mL}$ and $0.37 \mu \mathrm{g} / \mathrm{mL}$, respectively.

Generally, the citrus oils are characterized by high percentage of limonin (more than 90\%) (Hérent et al., 2007; Pultrini et al., 2006; Merle et al., 2004). Among the two limonoids (limonin and nomilin), limonin is the dominant limonoid found in almost all citrus cultivar oils. These results are well supported by the findings of Manners et al. (2003), Rouseff and Fisher (1980) and Kefford (1955). Similar studies of other citrus species such as C. limon, C. sphaerocarpa, C. sinensis $\times$ Poncirus trifoliata and $C$. reticulata also showed that the oil have about $70 \%$ limonin as the major components. Meanwhile the oils from lemon, lime, orange and grapefruits had high level of nomilin and limonin (Buettner et al., 2003; Miller et al., 1994; Lam et al., 1994). Vekiari et al. (2002) reported that the main components of citrus essential oils were limonene, $\beta$-pinene, myrcene, neral, geranial, neryl acetate and $\beta$-caryophyllene. Citrus peel oils also have limonin as a major component of essential oils like commercial Brazillian Murcot Tangerines (Feger et al., 2003), C. reticulate, C. sinensis, C. paradisii (Kamal et al., 2011; Ahmad et al., 2006). It is concluded from the present study that, among the seven citrus cultivars, red blood orange had the highest level of limonin while rough lemon had the highest level of nomilin.

Table 1. Quantities of limonin and nomilin in citrus varieties

\begin{tabular}{|c|c|c|c|c|c|c|}
\hline $\begin{array}{l}\text { Sr. } \\
\text { no. }\end{array}$ & Common name & Botanical name & $\begin{array}{l}\text { Nomilin } \\
(\mu \mathrm{g} / \mathrm{mL})\end{array}$ & $\begin{array}{l}\text { Ret. time } \\
\text { (Min) }\end{array}$ & $\begin{array}{l}\text { Limonin } \\
(\mu \mathrm{g} / \mathrm{mL})\end{array}$ & $\begin{array}{l}\text { Ret. time } \\
\text { (Min) }\end{array}$ \\
\hline 1 & Chakutra & (Citrus grandis) & 6.01 & 1.88 & 39.87 & 3.26 \\
\hline 2 & Kinnow & (Citrus reticulate) & 3.91 & 1.24 & 99.62 & 3.29 \\
\hline 3 & Musambi & (Citrus sinensis var musambi) & 41.67 & 1.63 & 42.63 & 3.17 \\
\hline 4 & Narangi & (Citrus mitis) & 11.85 & 1.50 & 0.77 & - \\
\hline 5 & Red blood orange & (Citrus sinensis var red blood orange) & 1.49 & 1.87 & 479.77 & 3.54 \\
\hline 6 & Rough lemon & (Citrus jambhiri) & 54.23 & 1.70 & 0.00 & - \\
\hline 7 & Succari & (Citrus sinensis var succari) & 0.37 & 1.41 & 426.77 & 3.55 \\
\hline
\end{tabular}



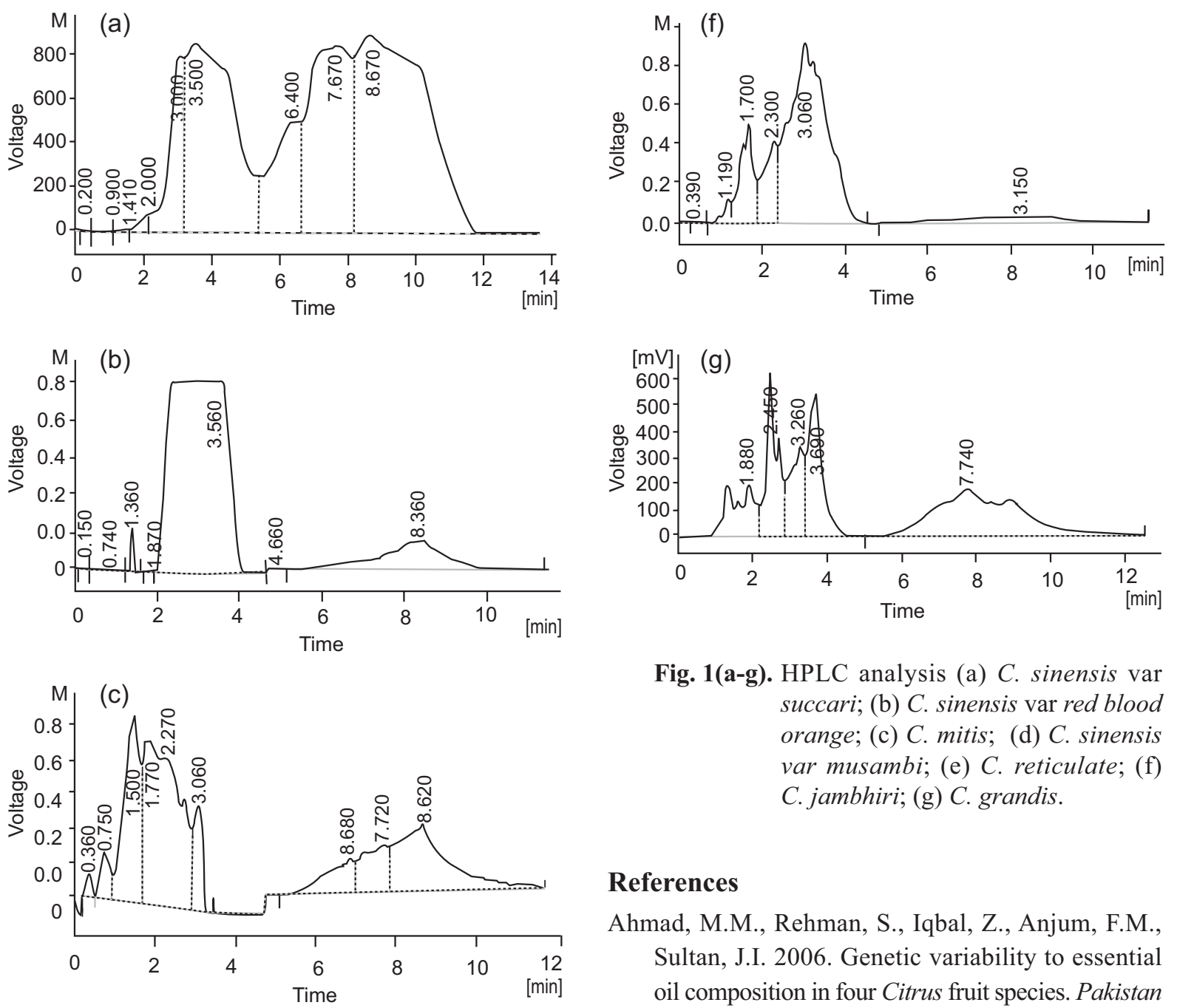

Fig. 1(a-g). HPLC analysis (a) C. sinensis var succari; (b) C. sinensis var red blood orange; (c) C. mitis; (d) C. sinensis var musambi; (e) C. reticulate; (f) C. jambhiri; (g) C. grandis.

\section{References}

Ahmad, M.M., Rehman, S., Iqbal, Z., Anjum, F.M., Sultan, J.I. 2006. Genetic variability to essential oil composition in four Citrus fruit species. Pakistan Journal of Botany, 38: 319-324.

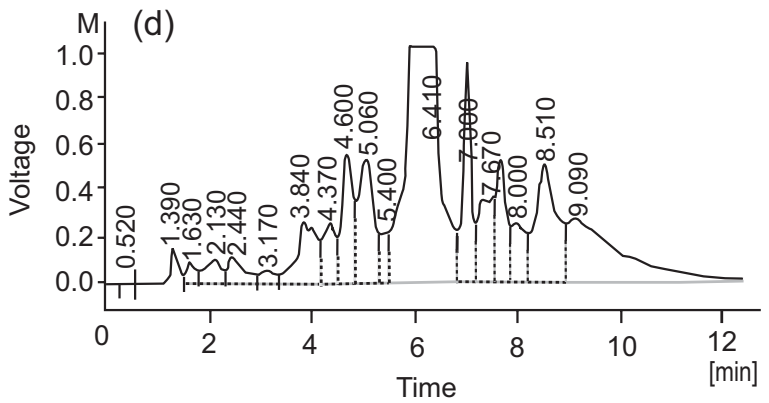

Buettner, A., Mestres, M., Fischer, A., Guasch, J., Schieberle, P. 2003. Evaluation of the most odouractive compounds in the peel oil of clementines (Citrus reticulata blanco cv. clementine). European Food Research and Technology, 216: 11-14.

Champage, D.E., Koul, O., Isman, M.B., Scudder, G.G.E., Towers, G.H.N. 1992. Biological activity of limonoids from Rutales. Photochemistry, 31: 377-394.

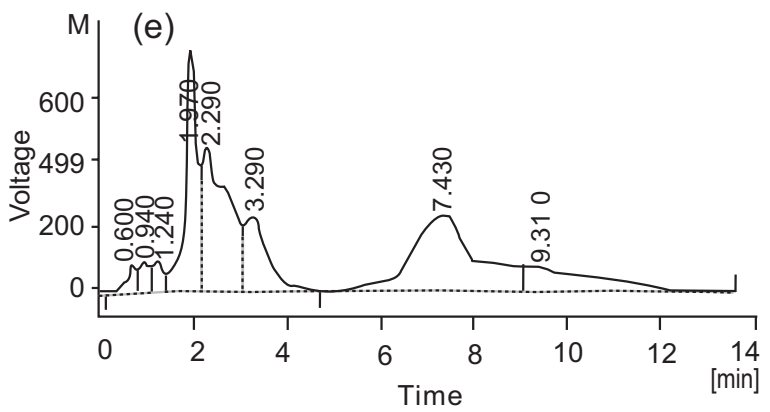

Dandekar, D.V., Jayaprakasha, G.K., Patil, B.S. 2008. Simultaneous extraction of bioactive limonoid aglycones and glucoside from Citrus aurantium L. using hydrotropy. Zeitschrift fur Naturforschung, 63: 176-180.

Faisal, H., Waseem, A., Essam, A.S.S. 2011. Mosquito larvicidal activity of citrus limonoids against Aedes albopictus. Parasitology Research, 109: 221-229.

Feger, W., Brandauer, H., Ziegler, H. 2003. Analytical 
investigation of Murcott (Honey) tangerine peels oil. Journal of Essential Oil Research, 15: 143147.

Gutierrez, C., Fereres, A., Reina, M., Cabrera, R., Gonzalez-Coloma, A. 1997. Behavioral and sublethal effects of structurally related lower terpenes on Myzus persicae. Journal of Chemical Ecology, 23: $1641-1650$.

Hasegawa, S. 2000. Biochemistry of limonoids in citrus. In: Citrus Limonoids, Functional Chemicals in Agriculture and Food, M. A. Berhow, S. Hasegawa and G. D. Manners (eds), pp. 9-30, American Chemical Society 758, Oxford University Press, Washington, USA.

Hérent, M.F., De-Bie, V., Tilquin, B. 2007. Determination of new retention indices for quick identification of essential oils compounds. Journal of Pharmaceutical and Biomedical Analysis, 43: 886-892.

Jayaprakasha, G.K., Singh, R.P., Pereira, J., Sakariah, K.K. 1997. Limonoids from Citrus reticulate and their moult inhibiting activity in mosquito Culex quinquefasciatus larvae. Phytochemistry, 44: 843846.

Kamal, G.M., Anwar, F., Hussain, A.I., Sarri, N., Ashraf, M.Y. 2011. Yield and chemical composition of Citrus essential oils as affected by drying pretreatment of peels. International Food Research Journal, 18: 1275-1282.

Kefford, J.F. 1955. Recent additions to knowledge of the chemistry of citrus fruits. Reviews of Pure and Applied Chemistry, 5: 77-98.

Klocke, J.A., Kubo, I. 1982. Citrus limonoids by product as insect control agent. Entomologia Experimentalis et Applicata, 32: 299-301.

Lam, L.K.T., Zang, J., Hasegawa, S. 1994. Citrus limonoid reduction of chemically induced tumorigenesis. Food Technology, 48: 104-108.

Langenheim, J.H. 1994. Higher plant terpenoids: a phytocentric overview of their ecological roles. Journal of Chemical Ecology, 20: 1223-1280.

Manners, G.D., Breksa, A.P., Schoch, T.K., Hidalgo, M.B. 2003. Analysis of bitter limonoids in citrus juices by atmospheric pressure, chemical ionization and electrospray ionization liquid chromatographymass spectrometry. Journal of Agriculture and Food Chemistry, 51: 3709-3714.

Merle, H., Moron, M., Blázquez, M.A., Boira, H. 2004. Taxonomical contribution of essential oils in mandarins cultivars. Biochemistry and Systematic Ecology, 32: 491-497.

Miller, E.G., Gonzales-Sanders, A.P., Couvillon, A.M., Binnie, W.H., Hasegawa, S., Lam, L.K.T. 1994. Citrus limonoids as inhibitors of oral carcinogenesis. Food Technology, 48: 110-114.

Morris, P., Robbins, M. 1997. Manipulating the chemical composition of plants. Iger Innovation, 12-14.

Ohta, H., Fong, C.H., Berhow, M., Hasegawa, S. 1993. Thin-layer and high-performance liquid chromatographic analyses of limonoids and limonoid glucosides in Citrus seeds. Journal Chromatography A, 639: 295-302.

Poulose, S.M., Harris, E.D., Patil, B.S. 2005. Citrus limonoids induce apoptosis in human neuroblastoma cells and have radical scavenging activity. The Journal of Nutrition, 135: 870-877.

Pultrini, A.M., Galindo, L.A., Costa, M. 2006. Effects of the essential oil from Citrus aurantium L. in experimental anxiety models in mice. Life Sciences, 78: $1720-1725$.

Rohloff, J. 2003. Cultivation of herbs and medicinal plants in Norway-essential oil production and quality control. Ph.D. Thesis (Dissertation), 57 pp., The Plant Biocentre, Department of Biology, Faculty of Natural Sciences and Technology, Norwegian University of Science and Technology, NTNU-77, 57, Norway.

Rouseff, R.L., Fisher, J.F. 1980. Determination of limonin and related limonoids in citrus juices by high performance liquid chromatography. Analytical Chemistry, 52: 1228-1233.

Sarker, S.D., Latif, Z., Gray, A.I. (eds). 2005. Methods in biotechnology. In: Natural Product Isolation, vol. 20, pp. 1-25, $2^{\text {nd }}$ edition, Humana Press, Totowa, New Jersey, USA.

Schoch, T.K., Manners, G.D., Hasegawa, S. 2002. Recovery of limonoid glucosides from citrus molasses. Journal of Food Science, 67: 3159-3163.

Schoch, T.K., Manners, G.D., Hasegawa, S. 2001. Analysis of limonoid glucosides from citrus by electrospray ionization liquid chromatographymass spectrometry. Journal of Agriculture and Food Chemistry, 49: 1102-1108.

Sohail, E., Ahmed, E., Kiku, M., Chae, W.L. 2005. Limonoids are as cancer chemo preventive agents. Journal of the Science of Food and Agriculture, 3: 339-345. 
Tada, K., Takido, M., Kitanaka, S. 1999. Limonoids from fruit of Melia toosendan and their cytotoxic activity. Phytochemistry, 51: 787-791.

Tholl, D. 2006. Terpene synthases and the regulation, diversity and biological roles of terpene metabolism. Current Opinion Plant Biology, 9: 297-304.

Vekiari, S.A., Protopapadakis, E.E., Parthena, P., Dimitrios, P., Panou, C., Vamvakias, M. 2002. Composition and seasonal variation of the essen- tial oil from leaves and peel of a Cretan lemon variety. Journal of Agriculture and Food Chemistry, 50: 147-153.

Widmer, W.W., Montanari, A.M. 1996. The potential for citrus phytochemicals in hypernutritious foods. In: Hypernutritious Foods, J. W. Finley, D. J. Armstrong, S. Nagy and S.F. Robinson (eds), pp. 75-90, AG Science, Auburndale, Florida, USA. 